\title{
ЕКОЛОГІЯ
}

УДК $502.3+502.5$

doi: $10.25128 / 2078-2357.19 .2 .11$

\author{
П. С. ГНАТІВ, І. Я. КАПРУСЬ, П. Р. ХІРІВСЬКИЙ, О. Д. ЗИНЮК, Б. В. КРЕКТУН, \\ Ю. Я. КОРІНЕЦЬ, А. М. БУЧКО, О. В. ЗЕЛІСКО, Н. Є. ПАНАС, Н. Я. ЛОПОТИЧ, \\ М. Я. ОНИСКОВЕЦЬ \\ Львівський національний аграрний університет, \\ вул. Володимира Великого, 1, м. Дубляни, Жовківський район, Львівська область, 80381 \\ e-mail: kaprus63@gmail.com
}

\section{ЕКОЛОГІЯ ТА СЕРЕДОВИЩЕЗНАВСТВО ЯК НАУКИ І СПЕЦАЛЬНОСТІ}

Проаналізовано тенденції розвитку науково-методологічної і навчально-методичної сфери, пов'язаної з проблематикою поглиблення екологічних знань, екологізації сфер виробничої i невиробничої діяльності, зокрема освітньої галузі. Окреслені світові тенденції та основні риси теперішнього стану в екологічній освіті в Україні. Обгрунтована необхідність виходу на світові стандарти вивчення й оцінки стану природного довкілля і довкілля людини. Показана схема методологічного структурування й удосконалення нової в Україні, але самодостатньої у європейських країнах, сфери досліджень і практичних знань - інвайронментології або середовищезнавства. Наведено перелік пріоритетних дисциплін для набуття фаху за спеціальністю «Технології захисту навколишнього середовища». Диференціація сфер дослідження і студіювання загальної екології і середовищезнавства дасть змогу упорядкувати й поліпшити якість і темпи екологізації суспільної свідомості. Впровадження у виробництво ідей 3 технологій захисту довкілля поліпшить результати діяльності захисників довкілля і природи, а також сприятиме удосконаленню фундаментальних екологічних досліджень.

Ключові слова: середовище природне, середовище антропізоване, забруднення, інвайронментологія, екологія, технології.

Швидкий поступ інформаційного суспільства, технічний прогрес у виробництві та експоненціальний ріст людської популяції сьогодні спонукає замислитися над перспективою людства як всепланетного явища. Раніше гармонійне еволюційне «вмонтування» природою приматів у біосферу не спричиняло жодних геологічних чи екологічних загроз іiі самодостатньому існуванню [1]. Відомі мінімум чотири космогенні катастрофічні впливи на біоту Землі, які спричиняли зникнення великої кількості видів, проте потужні хвилі еволюції організмів, аж до виникнення приматів, все більше урізноманітнювали життя на Землі [8]. У нашу добу ми відчуваємо загрозу навислої катастрофи, проте вже не 3 космосу, а від самої людської популяції, котра стала всепланетною геологічною силою. Сукупна людська активність безпосередньо загрожує збалансованому існуванню біогеосфери та збереженню біоти на планеті в успадкованому від наших предків вигляді [6].

Оцінюючи глибину геологічних антропогенних змін на Землі, наш сучасник, нобелівський лауреат Поль Крутцен, у 1999 році висловив думку про початок нового після Голоцену геологічного періоду, який назвав Антропоценом. Першим стратиграфічним підтвердженням його початку вчені визнали геологічний прошарок антропогенних 
радіоактивних ізотопів в осадових породах і льодовиках Гренландії, які датують серединою XX ст. - початком ядерної ери планети [7]. Тому захист глобальної екосистеми (біогеосфери), від подальшого їі руйнування - головне завдання свідомого суспільства. Для цього потрібні точні й глибокі знання з екології та їх найширша популяризація. У всьому світі екологізація суспільної свідомості та виробничої діяльності набуває пріоритетного статусу.

Системний розвиток науки й освіти в сфері екології, світовий досвід та українські реалії дещо розходяться у напрямах і способах реалізації нагальних рішень.

До початку XXI ст. в Україні вся сукупність знань про живі системи, взаємовідносини між людським суспільством і біосферою та природою загалом, про проблеми захисту природного довкілля планети окреслилася у двох, умовно розмежовуваних блоках. Перший блок знань - власне, екологічний; другий - дещо ширший, соціоекологічний. Основою першого блоку $є$ класична екологія як розділ біології. Галузевими відгалуженнями ії стали прикладні екології, охорона природи й природного довкілля. Другий блок грунтується на соціоекології (у ред. Г. Бачинського [1], екогомології [5], геосоціосистемології [4] теоретичних концепціях про структуру й роботу створених людьми природно-соціальних систем. У західних наукових колах упродовж останньої чверті XXI ст. на повну силу розквітла інвайронментологія (інженерія довкілля тощо) або середовищезнавство - дослідження, контроль якості й захист навколишнього щодо людини середовища (ії довкілля).

Проте в науковій та освітній сфері України в царині екологічних досліджень, студіювання спеціальних знань за фахом екологія, охорона навколишнього середовища й природокористування належного порядку як у структурі, так і в термінології до тепер немає [3, 4].

У сучасному інформаційному суспільстві наукові знання і сфери освіти продовжують «відгалужуватися», утворюючи дочірні види наук. Такою є нинішня ситуація 3 біологією, екологією, охороною природи та охороною довкілля людини. За принципами А. Сен-Симона, О. Конта можна і необхідно уточнювати й розмежовувати сфери компетенції новітніх відгалужень класичної біології, промислової гігієни та безпеки життєдіяльності, токсикології тощо [3]. Розвиненість і розгалуженість сфер науки, наукової та інноваційної діяльності визначає ступінь цивілізованості кожної держави та її спрямованість на суспільний прогрес.

У структурі екологічних наук і охорони довкілля в Україні донедавна була певна невизначеність - хто має координувати розв'язання глобальних проблем захисту навколишнього середовища в державі і представляти іiі на світовій арені для координації міжнародної діяльності у цих сферах. 3 іншого боку, важливо визначитися, як розвивати фундаментальну екологію як науку біологічну та як бути з охороною довкілля як наукою та специфічною освітньою сферою.

Тепер в Україні нарешті почали приймати у ЗВО навчальний план з підготовки фахівців за спеціальністю 183 «Технології захисту навколишнього середовища» у галузі знань «Виробництво та технології». Проте, за незрозумілих причин сільськогосподарська екологія (галузь знань: 20 - Аграрні науки та продовольство; спеціальність: 201 - Агрономія та 204 Технологія виробництва та переробки продукції тваринництва) залишилися поза увагою «Переліку галузей знань і спеціальностей, за якими здійснюється підготовка здобувачів вищої освіти (Перелік 2015)».

Mema роботи - показати можливий науково-методологічний підхід до формування освіти із загальної екології, як біологічної науки, та інвайронментології або середовищезнавства, як набагато ширшої міждисциплінарної прикладної сфери знань із охорони навколишнього для людини середовища, а також в найзагальніших рисах висвітлити об’єкт і предмет дослідження деяких новітніх дисциплін прикладного рівня за планом «Технології захисту навколишнього середовища».

Методи досліджень. Для пошуку шляхів розв'язання проблеми застосований порівняльно-аналітичний метод, що грунтується на системному аналізі конкретних складових цілісної системи науки й освіти у сфері екології та захисту навколишнього середовища [3]. 
Обговорення проблеми. Теоретичні і прикладні аспекти освіти та досліджень із загальної екології як біологічної науки та інвайронментології або середовищезнавства розглянемо окремими частинами.

Біоекологія як класична наука. Швидкоплинний прогрес біологічних наук, зокрема у розділі екології, поступова «екологізація» сфер людської діяльності з одного боку та критичне загострення протиріччя між економічним розвитком цивілізації й вичерпністю біотичних ресурсів на планеті 3 іншого, потребують пошуку наукових методів оцінки ризиків та ефективних шляхів запобігання нищенню природи $[3,4]$.

Екологія має предметом свого дослідження всі взаємовідношення живих і неживих компонентів природи. Як біологічна наука екологія вивчає взаємовідношення живих істот та їх сукупностей між собою і з навколишнім біотичним та абіотичним середовищем, структурнофункціональні властивості екосистем - від найменших консорційних до біогеосфери включно, історію й еволюцію, природну й антропогенну динаміку цих систем, їхні корисні чи небезпечні для людини функції та спроби невиснажливого їх використання [4].

Водночас, екологи покликані з'ясувати, якими механізмами створюється і підтримується еволюційна сталість природних комплексів, як впливають стохастичні й космогенні чинники на стрибкоподібні процеси в природі, що саме забезпечує збереження та зміну їх просторовочасової структури, як компонуються у них харчові ланцюги та кругообіг поживних речовин (біогеохімічні цикли), якими чинниками визначається їхній поступ та еволюція. Таким чином, екологія вивчає надорганізмовий і надпопуляційний рівні функціонування біотичних систем $\mathrm{i}$ сукупність або структуру зв' язків між організмами, популяціями та їх середовищем.

Екологія має фундаментальне завдання вивчати особливості існування живих систем у функціонально взаємопов' язаному з ними природному чи антропізованому середовищі, їхню стійкість до руйнівного впливу виробничої діяльності людини, способи підтримування їхніх життєвих функцій і збереження їх у мінливому зовнішньому середовищі. Основними розділами екології як системи знань $є$ аутекологія (екологія організмів - організмових систем), демекологія (екологія популяційних систем), синекологія (екологія біотичних системугруповань) і біогеосферологія (вчення про глобальну екосистему - біогеосферу) [3].

У системі прикладних розділів виокремлені екологія рослин, грибів і тварин, лісових, степових (лучних), болотних систем, екологія аграрних систем (агроекологія), екологія водних (суходільних і морських) систем (гідроекологія й океанологія), екологія міських систем (урбоекологія), екологія людини як живої істоти (але не як особистості, члена суспільного утвору - соціуму) (рис. 1).

Екологія є засадничою базою для прикладної науки - охорони природи (фітосозології, зоосозології, ландшафтосозології тощо). Ці науки покликані розробляти всю сукупність системних заходів, спрямованих на збереження біотичного і ландшафтного різноманіття, територіальних природоохоронних об'єктів (резерватів, заповідників, заказників, пам'яток природи, біотопів тощо), місць трапляння рідкісних, ендемічних, реліктових видів та їхніх угруповань, зрештою, рідкісних чи унікальних середовищ (екотопів) для формування та існування таких самих біоугруповань, реінтродукції та інтродукції в науково обгрунтованих випадках тощо.

Отже, об'єкт і предмет дослідження екології у світовій науковій практиці давно визначені. Проте, в Україні у цьому плані ще панує певний «плюралізм», породжений популізмом навколо проблем захисту довкілля. У вітчизняній науці й освіті досі існують як одне ціле «хірургічно» не розділені, ще зовсім недавно народжені радянською епохою іiі розвитку, «сіамські близнюки» - екологія й охорона довкілля. Виключення становить відбрунькована екологічна безпека, про яку варто говорити окремо, адже це - технічна сфера, на думку її творців і прихильників. 


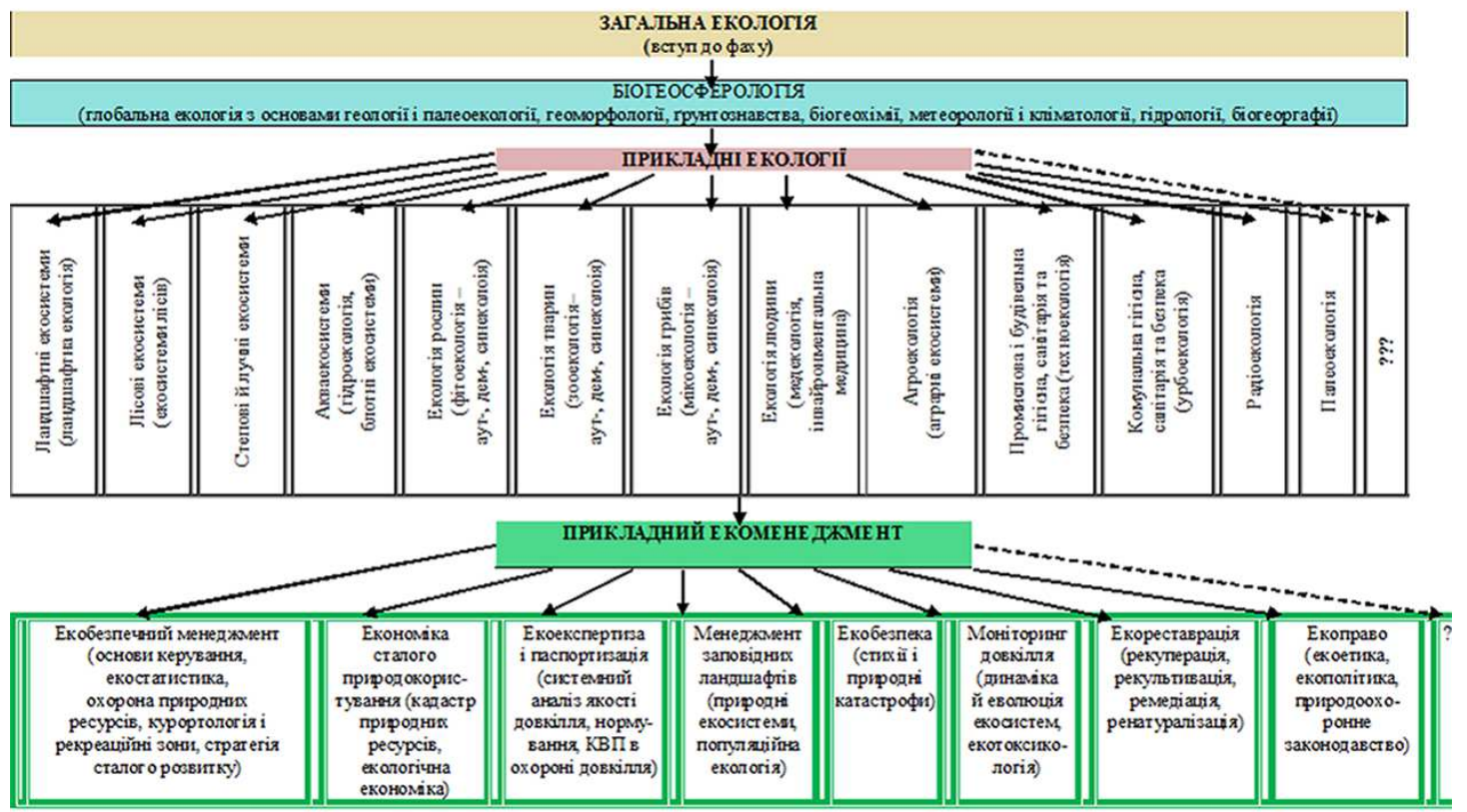

Рис. 1. Структура загальної екології як біологічної науки - теоретичної основи прикладного екоменеджменту, охорони природи й природних ресурсів

Об'єкт і предмет інвайронментології як новітньої інженерно-біологічної науки. Новітньою ознакою нашої доби $є$ поглиблення проблеми збереження здорового довкілля. Перед сучасною «людиною розумною» постали завдання: постійно стежити за змінами середовища, у якому існують природні, штучні екосистеми та саме людство; пізнавати закономірності й прогнозувати ці зміни під впливом різних техногенних і природних чинників; вивчати способи збереження довкілля у сприятливих для суспільства параметрах; упереджувати розвиток руйнівних процесів. Системна роль людини на планеті Земля - не регулювати біосферні процеси, а всіма доступними засобами запобігати дестабілізації та руйнуванню всіх геосфер як системних складових біогеосфери - атмосфери, гідросфери, літосфери, педосфери, і біоти (біосфери - у конкретному значенні) [3, 4, 9]. А це вже об'єкт, предмет і завдання значно ширшого плану, ніж має екологія як розділ біології. Власне сама екологія у цьому контексті виступає лише однією із невід'ємних граней комплексного дослідження природного середовища Землі.

Тому в розвинутих країнах сьогодні значно вагомішу позицію у громадській свідомості займає інвайронменталістика. У наукових колах та освітній сфері набагато актуальнішою, ніж екологія, є інвайронментологія (від фр. environner - оточувати, оточити та гр. $\lambda$ ó $о \varsigma$ - вчення, наука) та споріднена 3 нею охорона довкілля (сукупність наукових і практичних методів, способів та заходів з охорони середовища існування людей, розвитку людських цивілізацій [9]. Інвайронментологія (англ. - Environmental Science; укр. - середовищезнавство) - прикладна галузь знань про навколишнє еколого-соціально-економічне середовище розумової та виробничої діяльності людини й людських спільнот, про зважене використання природних, соціальних та економічних ресурсів і збереження цього середовища сприятливим для теперішніх і майбутніх поколінь. В Європі, Канаді й США вже понад три десятиліття ця наука активно розвивається. Під інвайронментологією там розуміють науку про навколишнє середовище (англ. - Environmental Science: Chiras, 1994). Провідні університети Світу кожних 3-4 роки видають оновлені підручники під назвою «Environmental Science» (як у глобальному 
аспекті - A Global Concern [8], так і на рівні вивчення локальних взаємозв'язків i взаємовідношень - A Study of Interrelationships [8, 9].

Інвайронментологія як наукова система має всі оригінальні атрибути самодостатньої наукової галузі, які роблять іiі якісно відмінною від загальної екології, промислової i комунальної гігієни, техногенної безпеки й безпеки життєдіяльності та створюють емерджентний результат - комплексну науку про людське довкілля.

Сьогодні інвайронментологія (середовищезнавство) стала науковою базою для підготовки фахівців у галузі знань «Виробництво та технології» за спеціальністю «Технології захисту навколишнього середовища». I це - велика перемога здорового глузду у сфері освіти.

Об'єктом вивчення інвайронментології $\epsilon$ всі рівні природного середовища - від космічного до внутрішньоклітинного (i, вірогідно 3 урахуванням темпів розвитку нанотехнологій, навіть внутрішньоорганельного), а також усі рівні антропізованого середовища - від техногенно-виробничого до соціально-культурного й духовно-естетичного (рис. 2). Особлива увага надається компонентам неживої природи: стану атмосферного (аж до навколоземного космосу) середовища, земної кори і грунтового покриву, гідросфери (води суходолу, океанів й морів). Унікальним явищем природи є різнорівневе біотичне - внутрішньоекосистемне та внутрішньоорганізмове середовище.

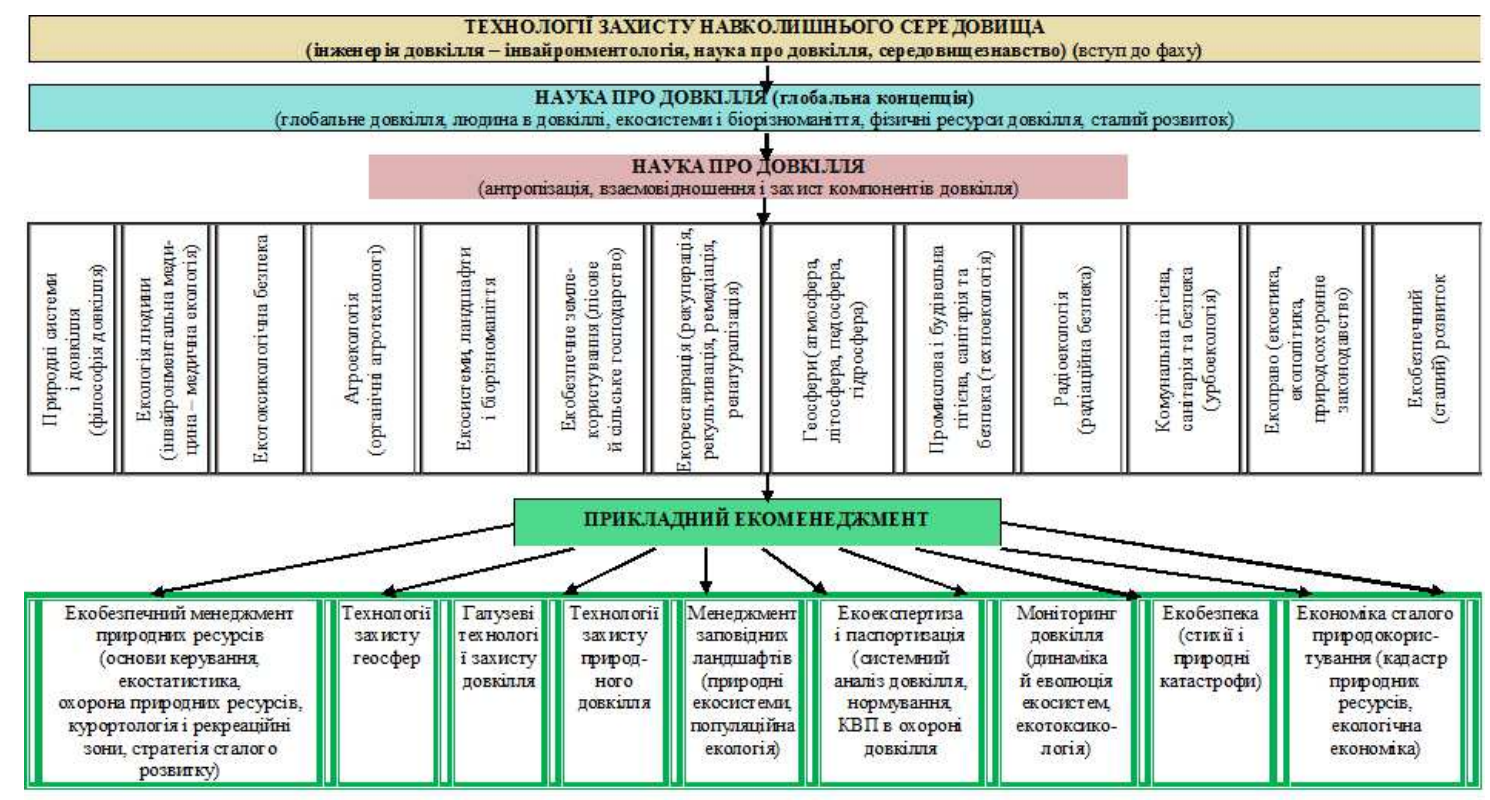

Рис. 2. Структура науки про довкілля (навколишнє середовище) - теоретичної основи прикладних технологій захисту природного довкілля і довкілля людини та охорони навколишнього середовища

Предметом дослідження середовищезнавства $€$ наукові основи збалансованого співіснування середовищетвірних живих і неживих природних систем та людської спільноти, способів розумного використання речовинно-енергетичних природних ресурсів на благо людства без руйнування чи розбалансування природного середовища.

Метою середовищезнавства є розроблення й утвердження у свідомості людей розумних принципів співіснування природних і суспільних середовищетвірних систем у навколишньому середовищі задля збереження можливості задоволення теперішніх і майбутніх поколінь своїх матеріальних і духовних потреб.

Середовищезнавство досліджує засадничі (філософські, матеріалістичні, етичні тощо) закономірності виникнення й еволюції та формулює принципи розуміння нашого навколишнього середовища, місце й унікальну роль у ньому біотичних систем. Ця наука 68 ISSN 2078-2357. Наук. зап. Терноп. нац. пед. ун-ту. Сер. Біол., 2019, № 2 (76) 
покликана обгрунтувати гармонійне місце і роль людської спільноти, а також розумні й зважені засади промислового, аграрного, комунального й рекреаційного господарювання людини в навколишньому природному середовищі. Ї̈̈ завданням $\epsilon$ пізнання й обгрунтування засад розумного керування середовищетвірними функціями всіх (живих і неживих) природних систем і використання матеріальних ресурсів. I врешті-решт, середовищезнавство повинно адекватно оцінювати теперішні наслідки, прогнозувати й надавати прагматичні та ефективні пропозиції щодо способів вирішення сучасних і майбутніх проблем економічної експлуатації природного середовища й земних матеріальних ресурсів для того, щоб убезпечити нинішнє $\mathrm{i}$ майбутні покоління від катаклізмів і катастроф.

Предмет і завдання освіти в екології. Усі питання, що належать до розділу знань про довкілля, в Україні розпорошені у підрозділах загальної екології і в різноманітних прикладних: екології людини, техноекології, урбоекології, агроекології тощо. Саме таким чином були дотепер сформовані навчальні плани вищих навчальних закладів та освітні стандарти для бакалаврів $з$ екології, охорони навколишнього середовища та раціонального використання природних ресурсів. У плані професійної підготовки після курсу «загальна екологія» у природничо-науковому циклі маємо зокрема такі обов'язкові дисципліни, як «агроекологія» «лісівництво і лісові ландшафти» (лісова екологія), «ландшафтна екологія», «екологія міських систем» (урбоекологія), «техноекологія», «екологія людини», «екологічна безпека», «екологічна експертиза», «організація управління в екологічній діяльності», «екологічне право» тощо. За вибором навчального закладу пропоновані й такі дисципліни, як: «соціоекологія», «міське комунальне господарство», «системи водокористування», «будівельна екологія», «геохімія техногенезу». На вибір самих студентів, окрім інших дисциплін, запропонована «екологія транспорту». Спеціалісти з екології й охорони навколишнього середовища додатково у циклі професійно орієнтованих дисциплін повинні освоїти такі курси: «екологія ландшафтів», «промислова екологія», «екологічне інспектування» та інші [6].

Суть актуальної методологічної проблеми у розв'язанні простого питання: яка галузь знань повинна досліджувати й вивчати цивілізаційні завдання виживання людства у створеному ним довкіллі на умовах збереження навколишнього природного середовища на Землі? Це повинні робити загальна та прикладні екології (як це дотепер історично склалося в Україні), чи нарешті варто окреслити коло прикладних питань, яке повинна вирішувати самодостатня і добре розвинута у Світі галузь знань - середовищезнавство або наука про довкілля.

Предмет $\boldsymbol{i}$ завдання освіти в інвайронментології. Як система знань середовищезнавство [5, 8, 9], яке студіюють у зарубіжних університетах за сучасними підручниками, наповнене новітніми відомостями про еволюційну єдність матеріального неживого й живого світу, роль науки й духовності у його розумінні й збереженні. На сучасних науково-світоглядних принципах будується сприйняття та значення біотичних систем Землі, біорізноманітності й екосередовища всіх рівнів. Середовищезнавство вивчає історію виникнення людської популяції, іï перетворення у цивілізоване людське суспільство, а згодом у планетарну геологічну силу. 3 критичних позицій розглядаються різні сфери людської діяльності, такі як урбанізація, соціальна гігієна і здоров'я, агровиробництво, продовольче забезпечення і загрози, що виникають у цих секторах діяльності. В останні роки вчені виокремлюють навіть потребу у захисті й збереженні унікальних етнокультурних середовищ у їх природному ландшафті (етноекологія або ландшафтосозологія) на противагу урбанізації [3]. Невід'ємним розділом освіти про навколишнє середовище $\epsilon$ знання про фізичні речовинноенергетичні ресурси та значення стабільності неживих середовищетвірних систем. Тут необхідно отримати геологічні знання, вивчати атмосферні явища, клімат, водні ресурси, природні аномалії та стихії, а також способи їх контролю і захисту від забруднення, дестабілізації або виснаження.

Актуальним розділом середовищезнавства $є$ висвітлення глибинних проблем розвитку цивілізації та новітніх здобутків у таких галузях, як відновна і безпечна енергетика, мінімізація й знешкодження твердих і токсичних відходів, життєздатна урбанізація, неруйнівна стосовно 
природного середовища i ресурсів економіка, зважена політика i законодавство [8, 9]. Завершальною нотою у циклі освіти $є$ активна й оптимістична пропаганда необхідності запровадження в усі сфери людської діяльності принципів сталого (екобезпечного) розвитку, формування у широкої громадськості думки про невідворотність переходу на ощадливий спосіб життя індивіда й цивілізації, необхідність займати активну громадянську позицію у суспільстві щодо збереження довкілля.

Оскільки середовищезнавство - це широка й складна міждисциплінарна система знань, як прикладна наука, вона прагматично застосовує методи й засоби всіх природних і точних наук для всебічного пізнання структурно-функціональної будови навколишнього середовища.

Міждисциплінарна кооперація задля розроблення прогнозних сценаріїв його антропогенної трансформації 3 відповідною оцінкою наслідків і вірогідних оптимальних шляхів запобігання кризам укаже людству реальний оптимістичний шлях у майбутне та розумні способи подолання поточних проблем. Головний підсумок всебічних знань про навколишнє середовище - вироблення і прийняття системних рішень, правильних і безпечних для майбутнього [3, 5]

\section{Висновки}

«Технології захисту навколишнього середовища» як фахова спеціальність, що грунтується на знаннях теоретичних основ та практичних навичках в інвайронментології (середовищезнавстві), сьогодні $є$ чи не найважливішою, соціально значущою професією в прикладних сферах наукової й практичної діяльності.

Визнання в Україні інвайронементології (середовищезнавства) як цілісної науки й наведення ладу в освітній галузі сприятимуть зменшенню напруги від непродуманої людської діяльності у сфері природокористування. У свідомості людей та очільників виробних галузей і сфер невиробничої діяльності з плином часу запанує справжнє за суттю й за формою усвідомлення потреби вирішення гострих проблем навколишнього середовища, нагальної потреби його захисту, ощадливого використання природних ресурсів і захисту природного довкілля. Такі проблеми будуть вирішувати не екологи, а штатні фахівці, посадовці 3 організації використання конкретних технологій захисту й відновлення природної якості навколишнього середовища: природного довкілля і довкілля життя самої людини.

\section{References}

1. Bachynskyy, G. (1991). Socioecology: Theoretical and Applied Aspects. Kyiv: Naukova Dumka (in Ukrainian).

2. Hnativ, P. S. \& Holubec, M. A. (2008). Environmental science. Ecological Encyclopedia,3. 236-237 (in Ukrainian)

3. Hnativ, P. S., \& Khirivskyy, P. R. (2010). Theory of systems and system analysis in ecology. Lviv: Kamula (in Ukrainian).

4. Holubec, M. A., \& Hnativ, P. S. (2007). Fundamentally about ecology, environmental sciences, environmental protection, environmental protection and geosociosystemology. Ecology and Noosphereology, 18 (1-2), 7-15 (in Ukrainian).

5. Grodzynsky, D. M., \& Hnativ, P. S. (2014). Ecology and inviremontology: the formation of science and the structuring of education in Ukraine. Magazine Agrobiology and Ecology: Scientific and Technical Journal, 4 (1), 17-23 (in Ukrainian).

6. Grodzinsky D. M. Ecology. Ecological Encyclopedia ( $3^{\text {nd }}$ ed.). Kyiv: LLC "Center for Environmental Education and Information" (in Ukrainian).

7. Macfarlane, R. (2016). Generation Anthropocene: How humans have altered the planet for ever. https://www.theguardian.com/books/2016/ apr/01/generation -anthropocene-altered-planet-for-ever) (in Ukrainian).

8. Cunningham, W. P., \& Saigo, B. W. (2005). Environmental Science: a global concern. Boston-Toronto: Wm. C. Brown Publishers.

9. Enger, E. D., \& Smith, B. F. (2004). Environmental Science: a study of interrelationships. Boston-Toronto: Wm. C. Brown Publishers. 
P. S. Hnativ, I. Ja. Kaprus`, P. R. Xirivs`kyj, O. D. Zynjuk, B. V. Krektun, Yu. Ya. Korinecz`, A. M. Buchko, O. V. Zelisko, N. Ye. Panas, N. Ya. Lopotych, M. Ya. Onyskovecz'

Lviv National Agrarian University. st. Volodymyra Velykogo, Ukraine

\section{ECOLOGY AND ENVIRONMENTOLOGY AS SCIENCE AND DISCIPLINE}

The tendencies in the development of the scientific-methodological and educational-methodical sphere related to the problems of deepening ecological knowledge, the ecologization of the spheres of productive and non-productive activities and education in particular, are analyzed. The world tendencies and main features of the current situation in environmental education in Ukraine are outlined. The necessity of entering the world standards of studying and assessing the state of the natural environment and the human environment is emphasized. The scheme of methodological structuring and improvement of the new in Ukraine, but well-established in European countries, the field of research and practical knowledge - environmental science - is presented.

The environmental science is concerned with the study of all levels of the natural environment, from the cosmic to the intracellular, as well as all levels of the anthropic environment, from the technogenic to the productive, from the socio-cultural to the spiritual-aesthetic. A unique phenomenon of nature is the recognition of multi-level biotic - intra-ecosystem and intra-organismal environments.

The subject matter of environmental science is constituted by the scientific foundations of the balanced coexistence of the medium-forming animate and inanimate natural systems and the human community, the methods of rational use of real-energy natural resources for the benefit of mankind without the destruction of the environment.

The environmental science aims at the development and promotion of reasonable principles of coexistence of natural and social medium-forming systems in the environment in order to preserve the possibility of satisfying present and future generations of their material and non-material needs.

As a system of knowledge, the science of the environment is filled with new information about the evolutionary unity of the material inanimate and living world, the role of science and spirituality in its understanding and preservation. Based on modern scientific and philosophical principles, the perception and importance of the biotic systems, biodiversity and eco-means of all levels is grounded.

The environmental science studies the history of the emergence of the human population, its transformation into planetary geological force. Various spheres of human activity are considered, such as urbanization, social hygiene and health, agricultural production, food supply and threats typical of these activities. An inseparable part of education in environmental science is the knowledge of physical real-energy resources and the values of stability of inanimate medium-forming systems. Here, it is necessary to obtain geological knowledge, to study atmospheric phenomena, climate, water resources, natural disasters, as well as ways to control and protect them from pollution, destabilization or depletion.

The current section of environmental science deals with the problems of civilization development and the latest achievements in such areas as renewable and safe energy, minimization and neutralization of solid and toxic waste, sustainable urbanization, non-destructive for environment and resources economics, balanced policies and legislation. Nonetheless important is active and optimistic promotion of the necessity to introduce principles of sustainable (eco-safety) development in all spheres of human activity, the formation of the mindset on the inevitability of transition to an economical way of life of an individual and civilization, the need to take an active civil position in society to preserve the environment.

The list of priority disciplines for obtaining an education in the specialty of Environmental Protection Technologies is given. It is emphasized that the differentiation of the spheres of research and the study of general ecology and environmental science will allow us to streamline and improve the quality and pace of the ecologization of public consciousness. The implementation of above mentioned ideas will improve the results of environmental and nature protection activities, and will also contribute to the ongoing ecological research.

Key words: natural environment, anthropized environment, pollution, environmental science, ecology, technologies.

Надійшла 17.05.2019. 